\title{
A new assay for interleukin-1 in the presence of interleukin-2
}

\author{
Werner Falk, Peter H. Krammer and Daniela N. Männel \\ Institute for Immunology and Genetics, German Cancer Research Center, Heidelberg, F.R, G.
}

(Received 12 November 1986, revised received 12 December 1986, accepted 2 January 1987)

A simple and reliable assay for interleukin-1 (IL-1) is described which has the advantage over other assays that it is independent of interleukin-2 (IL-2) production by the test cells. The assay makes possible the detection of IL-1 in the supernatants of T cell populations. The ability of IL-1 to induce IL-2 receptor expression in the absence of $\mathrm{T}$ cell mitogen is the basis of this assay. Thus, proliferation of mouse thymocytes incubated in the presence of saturating concentrations of IL-2 $(10 \mathrm{U} / \mathrm{ml})$ was directly dependent on the concentration of IL-1. The sensitivity of the assay is comparable to the sensitivity of the classical thymocyte co-stimulator assay. Natural and recombinant human and murine IL-1 were measured in this test system with comparable sensitivity.

Key words: Interleukin-1; Interleukin-2; Bioassay

\section{Introduction}

The term interleukin-1 (IL-1) represents a group of low molecular weight proteins which are produced by a variety of cells and have a wide range of biological activities (Dinarello, 1985). The best known IL-1 producer cells are monocytes/macrophages, B cells (Scala et al., 1984) and epidermal cells (Luger et al., 1985). Production of IL-1 by cells of the $\mathrm{T}$ cell lineage has also been reported (Tartakovsky et al., 1986). The most widely used assays for IL-1 activity are the lymphocyte-activating factor (LAF) assay (Gery et al., 1972) and the thymocyte co-stimulator assay (Shaw et al., 1978).

Correspondence to: W. Falk, German Cancer Research Center, Im Neuenheimer Feld 280, D-6900 Heidelberg, F.R.G.

Abbreviations: IL, interleukin; ${ }^{3} \mathrm{H}-\mathrm{TdR},\left[6-{ }^{3} \mathrm{H}\right]$ thymidine; TCF1, T cell cytotoxicity-inducing factor 1 ; BSF1, B cellstimulating factor 1; LPS, lipopolysaccharide; PHA, phytohemagglutinin; LAF, lymphocyte-activating factor; hu, human; m, murine; $r$, recombinant; cpm, counts per minute.
Two other assay systems use $\mathrm{T}$ cell lymphomas which are inducible by IL-1 plus mitogen or the $\mathrm{Ca}$ ionophore $\mathrm{A}_{23187}$ (Conlon, 1983; Simon et al., $1985)$ to produce IL-2. This IL-2 activity is then measured with an IL-2-dependent cell line. Another assay was described by Kaye et al. (1983). In this assay growth of the $\mathrm{T}$ cell hybridoma D10.G4.1 is stimulated by IL-1 plus a monoclonal antibody to the $T$ cell antigen receptor. All these assays measure IL-1 more or less indirectly through IL-2 production. Therefore, samples which already contain IL-2-like activities - like most supernatants of $T$ cell-containing cultures - cannot be tested for their IL-1 content. In a recent publication (Männel et al., 1985) we have described another function of IL-1 in T cell activation, namely the induction of IL-2 receptor expression. Thus, in the standard co-stimulator assay two effects of IL-1, the induction of IL-2 receptors and IL-2 production (resulting in proliferation) are being measured. We have used this finding to devise a simple and reliable assay system for IL-1 
which measures only one effect of IL-1 (the induction of IL-2 receptor expression) and is therefore independent of endogenously produced IL-2.

\section{Materials and methods}

Mice

Male $\mathrm{C} 3 \mathrm{H} / \mathrm{HeJ}$ mice were purchased from Jackson Laboratories, Bar Harbour, ME. The animals were used at 4-10 weeks of age.

\section{Culture medium}

The culture medium used was RPMI 1640 (Gibco) with L-glutamine $\left(2 \times 10^{-3} \mathrm{M}\right)$ and supplemented with $10 \%$ heat-inactivated fetal calf serum, 2-mercaptoethanol $\left(3 \times 10^{-5} \mathrm{M}\right)$, gentamycin $(50 \mu \mathrm{g} / \mathrm{ml})$, and Hepes $(0.02 \mathrm{M})$.

\section{Reagents}

Phytohemagglutinin (PHA)-P and PHA-M were obtained from Sigma, $\left[6-{ }^{3} \mathrm{H}\right]$ thymidine $\left({ }^{3} \mathrm{H}-\mathrm{TdR}\right)$ was purchased from Amersham and had a specific activity of $50 \mathrm{Ci} / \mathrm{mmol}(185 \mathrm{GBq} / \mathrm{mmol})$.

\section{Preparation of purified human $I L-1$}

The protocol described by Kronheim et al. (1985) was used with a minor modification. Briefly, peripheral lymphocytes were obtained from healthy individuals undergoing leukapheresis. The cell suspension was diluted with phosphatebuffered saline and separated on a Ficoll cushion (Böyum, 1962). The interphase layer containing the mononuclear cells was washed four times with culture medium. Centrifugations were performed at $200 \times \mathrm{g}$. The cells were cultured in medium with $0.01 \%$ fetal calf serum and $0.01 \mathrm{mg} / \mathrm{ml}$ glutaraldehyde-fixed Staphylococcus aureus cells (Pansorbin, Calbiochem) in large petri dishes (177 $\mathrm{cm}^{2}$ ) at a density of $2 \times 10^{6} / \mathrm{ml}$. Incubation was done for $24 \mathrm{~h}$ at $37^{\circ} \mathrm{C}$ in $5 \% \mathrm{CO}_{2}$ and at $90 \%$ relative humidity. Sodium azide $(0.02 \%)$ was added to the cell-free supernatants. The supernatants were stored at $4^{\circ} \mathrm{C}$. The supernatants were adjusted to $10 \mathrm{mM}$ citrate and the $\mathrm{pH}$ was titrated to 4 with $20 \%$ hydrochloric acid. The material was applied to an SP-Sephadex (Pharmacia) column and the column was washed with 4 vols. of $10 \mathrm{mM}$ citrate $\mathrm{pH} \mathrm{4,} 150 \mathrm{mM}$ sodium chloride. A second wash was performed with four column volumes of
$10 \mathrm{mM}$ 2-( $N$-morpholino)ethane sulphuric acid (MES) buffer pH 5. Elution from the column was performed with $10 \mathrm{mM}$ Tris- $\mathrm{HCl} \mathrm{pH}$ 8.5. IL-1 activity eluted with the rise in $\mathrm{pH}$. The active fractions were pooled. This pool was applied to a mono-Q-column (FPLC apparatus, Pharmacia) which was equilibrated in $10 \mathrm{mM}$ Tris $\mathrm{pH} 8.5$. After application, the column was washed with 10 $\mathrm{ml}$ of starting buffer and then a sodium chloride gradient in $10 \mathrm{mM}$ Tris from 0 to $0.4 \mathrm{M}$ was applied. IL-1 activity eluted in the first fractions with a peak of activity at a molarity of $0.05 \mathrm{M}$. These fractions were pooled and stored at $4{ }^{\circ} \mathrm{C}$. Further purification was not considered necessary for our purposes.

\section{Preparation of purified mouse $I L-I$}

IL-1 was prepared from P388D1 cells by following the superinduction protocol of Mizel and Mizel (1981). Briefly, $2 \times 10^{6}$ adherent P388D1 cells were cultured in medium containing $10 \mu \mathrm{g} / \mathrm{ml}$ phorbol myristate acetate and $10 \mu \mathrm{g} / \mathrm{ml}$ cycloheximide for $4 \mathrm{~h}$. This medium was replaced by fresh medium containing $10 \mu \mathrm{g} / \mathrm{ml}$ actinomycin D. After $1 \mathrm{~h}$, the cells were washed three times and were cultured overnight in fresh medium. Cell-free supernatant was collected and protein was precipitated with ammonium sulfate (65\% saturation). After extensive dialysis the sample was applied to a Sephadex G-100 column. IL-1 activity eluted in one peak with a molecular weight around 15000 . The active fractions were pooled, dialyzed, sterilized by filtration and stored at $-20^{\circ} \mathrm{C}$.

\section{Other lymphokines}

Recombinant murine (mrIL-1) and human (hurIL-1) IL-1 $\alpha$ were generously provided by J.J. Farrar, Hoffman La Roche, Nutley, U.S.A. Highly purified human recombinant IL-2 (hurIL-2) from E. coli (Rosenberg et al., 1984; Wang et al., 1984) was a gift from Cetus Corporation, Emeryville, CA. Activity in $\mathrm{U} / \mathrm{ml}$ for rIL-1 is given as stated by the manufacturer $\left(1.5 \times 10^{6} \mathrm{U} / \mathrm{mg}\right.$ and $1.7 \times$ $10^{7} \mathrm{U} / \mathrm{mg}$ for mrIL-1 and hurIL-1 respectively, based on half-maximal stimulation). Activity of rIL-2 was calculated based on the NIH standard.

\section{Interleukin-I assays}

Single cell suspensions of $\mathrm{C} 3 \mathrm{H} / \mathrm{HeJ}$ thymo- 
cytes were cultured in culture medium in flat bottom 96-well plates at densities indicated in the paper. The total volume was $0.2 \mathrm{ml}$ containing the indicated lymphokines. When the classical costimulator assay was used, the PHA concentration was $1 \mu \mathrm{g} / \mathrm{ml}$ for PHA-P (Sigma) or $50 \mu \mathrm{g} / \mathrm{ml}$ for PHA-M (Sigma). When IL-2 was used as costimulator for IL-1, its concentration was as indicated up to $200 \mathrm{U} / \mathrm{ml}$. After 2-4 days of culture in $5 \% \mathrm{CO}_{2}$ and at $90 \%$ relative humidity at $37^{\circ} \mathrm{C}$, the cultures were pulsed for $4-6 \mathrm{~h}$ with $1 \mu \mathrm{Ci}$ /well of ${ }^{3} \mathrm{H}-\mathrm{TdR}$. The DNA was then precipitated onto glass fiber filters using a cell harvester and the radioactivity was measured in a liquid scintillation counter.

\section{Results}

We have previously described a second function for IL-1 besides its capacity to induce IL-2 secretion in $T$ cells. This other function is the induction of IL-2 receptor expression in thymic cell preparations. This finding offers the possibility of a test system for IL-1 which is not dependent on either the IL-2 concentration of the test sample itself or the induction of IL-2 by the IL-1 of the cell culture.

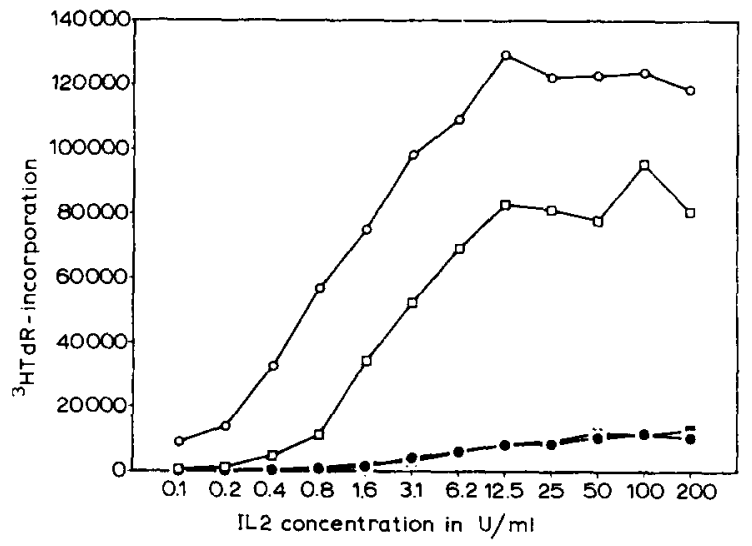

Fig. 1. IL-2 dose-response curves in the presence of different concentrations of IL-1. The IL-1 was mrIL-1, IL-2 was hurIL-2. $10^{6} \mathrm{C} 3 \mathrm{H} / \mathrm{HeJ}$ thymocytes were cultured for 4 days in the presence of $50 \mathrm{U} \mathrm{IL-1} / \mathrm{ml}(\mathrm{O}), 1 \mathrm{U} \mathrm{IL}-1 / \mathrm{ml}(\square), 0.1 \mathrm{U}$ IL-1/ml (•) and no IL-1 (D). IL-2 was titrated into these cultures at $\log _{2}$ dilutions. Before harvest the cultures were pulsed for $4 \mathrm{~h}$ with $1 \mu \mathrm{Ci} /$ well of ${ }^{3} \mathrm{H}-\mathrm{TdR}$. The data represent the mean of duplicate cultures given as counts per min (cpm).

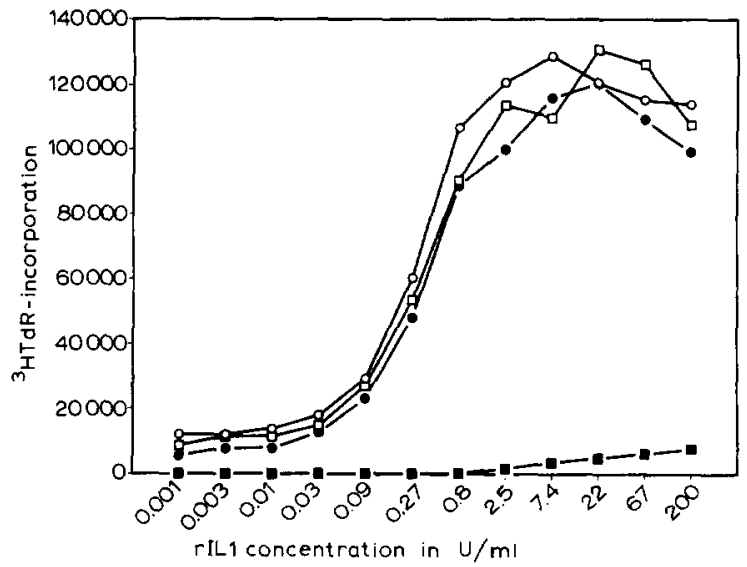

Fig. 2. IL-1 dose-response curves in the presence of different concentrations of IL-2. The IL-1 was mrIL-1, IL-2 was hurIL-2. $10^{6} \mathrm{C} 3 \mathrm{H} / \mathrm{HeJ}$ thymocytes were cultured for 4 days in the presence of $200 \mathrm{U} / \mathrm{ml} \mathrm{IL-2}(\mathrm{O}), 50 \mathrm{U} / \mathrm{ml} \mathrm{IL-2}(\square), 10 \mathrm{U} / \mathrm{ml}$

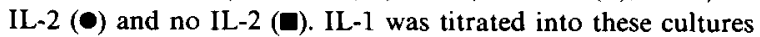
at $\log _{3}$ dilutions. Before harvest the cultures were pulsed for 4 $h$ with $1 \mu \mathrm{Ci} /$ well of ${ }^{3} \mathrm{H}-\mathrm{TdR}$. The data represent the mean of duplicate cultures given as cpm.

In order to have an IL-1 assay system which is independent of endogenous IL-2 it was necessary to define saturating concentrations of IL-2. IL-2 produced by thymocytes after IL-1 activation has no additional effect on proliferation in cultures saturated with IL-2. For that reason thymocytes were stimulated by a variety of concentrations of IL-1, and IL-2 was triated into these cultures. As shown in Fig. 1, a concentration of $10 \mathrm{U} / \mathrm{ml}$ of recombinant IL-2 was already sufficient to reach the plateau levels of proliferation. A further increase in IL-2 concentration did not increase proliferation. It was also evident that different plateau levels were reached with different concentrations of IL-1. Therefore, the level of proliferation in the presence of excess amounts of IL-2 was only dependent on the concentration of IL-1. To test this finding, IL-1 was titrated in the presence of different concentrations of IL-2. As seen in Fig. 2 the dose-response curves of recombinant IL-1 in the presence of more than $10 \mathrm{U} / \mathrm{ml}$ of recombinant IL-2 were practically identical.

\section{Effect of thymus cell concentration and time of incubation on the assay system}

In order to test whether cell density plays a role in our assay IL-1 was titrated at different cell 
concentrations. It was found that the IL-1 concentration at which half-maximal proliferation was measured in the presence of $50 \mathrm{U} / \mathrm{ml}$ of hurIL-2 was not significantly different between $3.8 \times 10^{4}$ and $6 \times 10^{5}$ cells/ well. Kinetic studies were performed to determine the optimal time of incubation for testing ${ }^{3} \mathrm{H}-\mathrm{TdR}$ incorporation. IL-1 titrations were set up in the presence of saturating amounts of IL-2 $(50 \mathrm{U} / \mathrm{ml})$ in replicate cultures. Replicates were pulsed with ${ }^{3} \mathrm{H}-\mathrm{TdR}$ and harvested on days 2, 3 and 4 of culture. Maximal proliferation was reached on day 3 , but the assay could be read as early as day 2 . However, the best stimulation index was obtained on day 4. It is important to note again that the IL-1 concentrations which induced half-maximal proliferation were not significantly different on the different days of harvest (data not shown).

Comparison of assay sensitivity with the classical co-stimulator assay using PHA as costimulator

Parallel titrations of IL-1 in the presence of either $50 \mathrm{U} / \mathrm{ml}$ of $\mathrm{IL}-2$ or $50 \mu \mathrm{g} / \mathrm{ml}$ of PHA-M were performed in order to compare the sensitivity of our assay system for IL-1 with the conventional co-stimulator assay using suboptimal concentrations of PHA. The cultures were tested on day 3 for ${ }^{3} \mathrm{H}$-TdR incorporation. The titers of IL-1 ob-

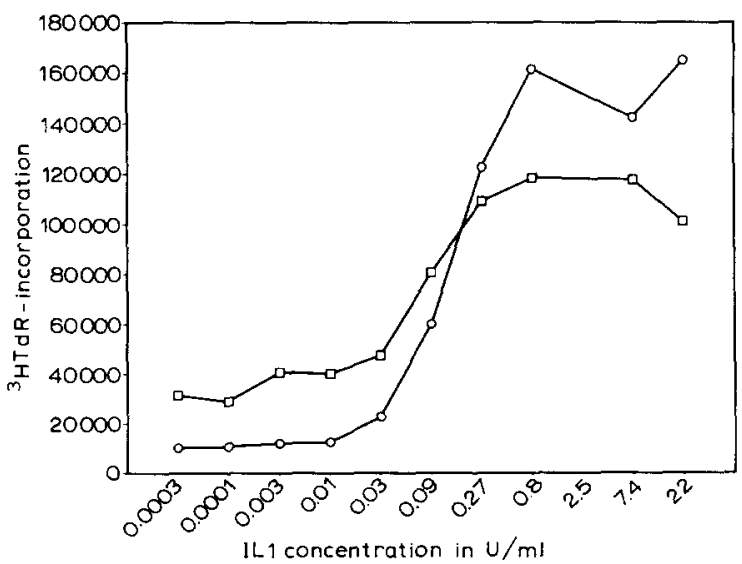

Fig. 3. Comparison of the PHA and IL-2 co-stimulator assay. $\mathrm{C} 3 \mathrm{H} / \mathrm{HeJ}$ thymocytes $\left(4 \times 10^{5} /\right.$ well $)$ were incubated in the presence of either hurIL-2 $(50 \mathrm{U} / \mathrm{ml})(\mathrm{O})$ or PHA-M (50 $\mu \mathrm{g} / \mathrm{ml})(\square) . \mathrm{mrIL}-1$ was titrated into these cultures in three-fold dilutions. The cells were incubated for 3 days. $4 \mathrm{~h}$ prior to harvest cells were pulsed with $1 \mu \mathrm{Ci} /$ well of ${ }^{3} \mathrm{H}-\mathrm{TdR}$. The data represent the mean of duplicate cultures given as cpm. tained in the two systems were identical (Fig. 3). This was true for more than $90 \%$ of the assays performed. In some experiments our assay was up to 15-fold more sensitive than the classical thymocyte co-stimulator assay. This might be explained by the fact that the PHA co-stimulator assay is performed using suboptimal concentrations of mitogen and that the thymic cells due to their heterogeneity react differently to these concentrations. Therefore, we concluded that the sensitivity of the two assays was comparable and that the co-stimulator assay using saturating concentrations of IL-2 was more reproducible. In addition, the stimulation index was usually higher in the new assay system. IL-2 titrations in both

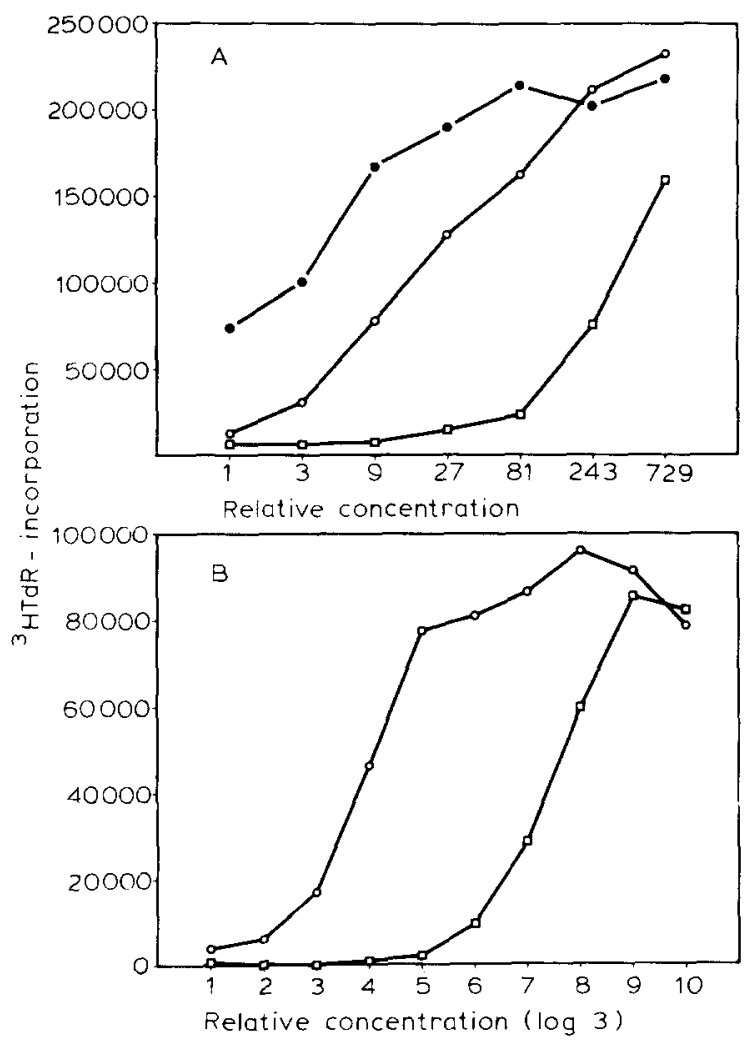

Fig. 4. Titration of different IL-1 molecules. C3H/HeJ thymocytes $\left(5 \times 10^{5} /\right.$ well) were cultured for 3 days in the presence of $50 \mathrm{U} / \mathrm{ml}$ of hurIL-2. Different IL-1 samples were added to the cultures in three-fold dilutions. $4 \mathrm{~h}$ prior to harvest $1 \mu \mathrm{Ci}$ /well of ${ }^{3} \mathrm{H}$-TdR was added to each well. The data represent the mean of duplicate cultures given as cpm. $A$ : (O) purified huIL-1 $\beta$; (ㅁ) partially purified natural mIL-1; (•)

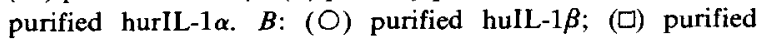
mrIL-1. 
assay systems were also compared after different times of incubation and at various cell densities. The assay sensitivity did not differ significantly under any of the conditions studied (data not shown).

Effect of different species of $I L-1$ in the new assay system

Different IL-1 molecules were compared to obtain information about the general value of the test system. Purified recombinant human IL-1 $\alpha$, purified natural human IL- $1 \beta$, recombinant mouse IL-1, and semi-purified natural mouse IL-1 from the P388D1 macrophage-like cell line were titrated under the conditions given in the legend to Fig. $4 A$ and $B$. It is clear from the figure that these different IL-1 molecules gave a positive signal in this test system. Also, the titration curves were superimposable and reached the same plateau, suggesting that the mechanisms of activation were similar for all IL-1 samples.

\section{Discussion}

A variety of assay systems is available to detect and quantitate IL-1. They are all based on the ability of IL-1 to induce IL-2 production in T cells or thymomas. All test systems are of similar sensitivity except the 'conversion assay' which seems to be the most sensitive (Conlon, 1983). In all systems the proliferation due to IL-2 is quantitated. Because of IL-2 contamination it has been impossible to determine IL-1 and IL-1-like activities in supernatants of cell populations containing cells of the T cell lineage. Only in exceptional cases of $T$ cell supernatants which were devoid of IL-2 could IL-1 activity be measured. We needed an assay system for IL-1 which was not influenced by IL-2. The assay which was developed was based on our previous finding (Männel et al., 1985) that IL-1 induces IL-2 receptor expression on murine thymocytes in the presence of IL-2 which results in proliferation. Using thymocytes in the presence of saturating amounts of IL-2 the proliferation induced was directly dependent on the IL-1 concentration and reached plateau levels which were dependent on the concentration of IL-1. The assay was highly reproducible and yielded titration curves with high stimulation indices.
The titers of IL-1 were independent of cell numbers over a range of at least one $\log _{10}$ and could be read as early as day 2 of culture. A longer culture period resulted in higher ${ }^{3} \mathrm{H}-\mathrm{TdR}$ incorporation and better stimulation indices but determination of the titer of IL-1 was the same. Sensitivity fluctuations as seen using suboptimal amounts of mitogen in combination with thymoma cells have not been observed in many experiments. When bacterial lipopolysaccharide (LPS) is excluded from the cultures, the requirement for thymocytes from the $\mathrm{C} 3 \mathrm{H} / \mathrm{HeJ}$ LPS low responder strain is not stringent. IL-1 could be measured in the same culture wells in which the assay was set up and transfer of supernatants was therefore not required. This eliminated an additional putative source of experimental error. Moreover, any source of IL-2 which is free of mitogen or IL-1-like activities can be used as growth factor. For these reasons the described assay is very simple, reliable and does not require long-term culture and recloning of unstable IL-1sensitive cell lines for assay. On the other hand, one has to keep in mind that all IL-1-like activities will give a positive signal in this assay. One of these activities is $T$ cell cytotoxicity-inducing factor 1 (TCF1) which like IL-1 induces proliferation of thymocytes (Falk et al., 1985). TCF1, however, is different from IL-1 with respect to cellular source and biochemical data. Another factor that was shown to stimulate IL-2-dependent cells is B cell-stimulating factor 1 (BSF-1), now termed interleukin-4 (Fernandez-Botran et al., 1986). This factor was also active in our IL-1 assay (data not shown). One also has to be aware of the fact that the concentration of $T$ cell mitogens must be rigorously controlled in the cultures, but this is true for all assays for IL-1.

In conclusion, our new assay for IL-1 is superior to other IL-1 assays in that it can measure IL-1 independent of IL-2 production. Thus, IL-1 titers in IL-2-containing supernatants can be determined.

\section{Acknowledgements}

We thank Heidi Darjes for expert technical assistance and Heidi Sauter for manuscript preparation. 
This work was partly financed by Grant 21-4Dr. Krammer from the BMFT.

\section{References}

Böyum, A. (1962) Isolation of mononuclear cells and granulocytes from human blood. Scand. J. Clin. Lab. Invest. Suppl. 21, 77.

Conlon, P.J. (1983) A rapid biologic assay for the detection of interleukin-1. J. Immunol. 131, 1280.

Dinarello, C.A. (1985) An update on human interleukin-1: From molecular biology to clinical relevance. J. Clin. Immunol. 5, 287.

Falk, W., Männel, D.N., Katzer, B., Kaltmann, B., Krammer, P.H., Diamantstein, T. and Dröge, W. (1985) Induction of IL 2 receptor expression and cytotoxicity of thymocytes by stimulation with TCF1. J. Immunol. 135, 1160.

Fernandez-Botran, R., Krammer, P.H., Diamantstein, T., Uhr, J.W. and Vitetta, E.S. (1986) B cell-stimulatory factor (BSF-1) promotes growth of helper $T$ cell lines. J. Exp. Med. 164, 580.

Gery, I. and Waksman, B.H. (1972) Potentiation of Tlymphocyte response to mitogens. II. The cellular source of potentiating mediator(s). J. Exp. Med. 136, 143.

Kaye, J., Porcelli, S., Tite, J., Jones, B. and Janeway, C.A. (1983) Both a monoclonal antibody and antisera specific for determinants unique to individual cloned helper $\mathrm{T}$ cell lines can substitute for antigen and antigen-presenting cells in the activation of $T$ cells. J. Exp. Med. 158, 836.

Kronheim, S.R., March, C.J., Erb, S.K., Conlon, P.J., Mochizuki, D.Y. and Hopp, T.P. (1985) Human inter- leukin-1. Purification to homogeneity. J. Exp. Med. 161, 490.

Luger, T.A., Köck, A. and Danner, M. (1985) Characterization of immunoregulatory cytokines produced by epidermal cells. Scand. J. Immunol. 21, 455.

Männel, D.N., Mizel, S.B., Diamantstein, T. and Falk, W. (1985) Induction of interleukin-2 responsiveness in thymocytes by synergistic action of interleukin-1 and interleukin- 2 . J. Immunol. 134, 3108.

Mizel, S.B. and Mizel, D. (1981) Purification to apparent homogeneity of murine interleukin-1. J. Immunol. 126, 834.

Rosenberg, S.A., Grimm, E.A., McGrogan, M., Doyle, M., Kawasaki, E., Koths, K. and Mark, D.F. (1984) Biological activity of recombinant interleukin-2 produced in Escherichia coli. Science 223, 1412.

Scala, G., Kuang, Y.D., Hall, R.E., Muchmore, A.V. and Oppenheim, J.J. (1984) Accessory function of human B cells. I. Production of both interleukin 1-like activity and an interleukin 1 inhibitory factor by an EBV-transformed human B cell line. J. Exp. Med. 159, 1637.

Shaw, J., Monticone, V. and Paetkau, V. (1978) Partial purification and molecular characterization of a lymphokine (co-stimulator) required for the mitogenic response of mouse thymocytes in vitro. J. Immunol. 120, 1967.

Simon, P.L., Laydon, J.T. and Lee, J.C. (1985) A modified assay for interleukin-1 (IL-1). J. Immunol. Methods 84, 85.

Tartakovsky, B., Kovacs, E.J., Takacs, L. and Durum, S.K. (1986) $\mathrm{T}$ cell clone producing an IL l-like activity after stimulation by antigen-presenting B cells. J. Immunol. 137, 160.

Wang, A., Lu, S.D. and Mark, D. (1984) Site-specific mutagenesis of the human interleukin-2 gene: structure-function analysis of the cystein residues. Science 224, 1431. 